\title{
Performance Investigation on Variations of Glass Cover Thickness on Solar Still: Experimental and Theoretical Analysis
}

\author{
Hitesh Panchal ${ }^{1}$
}

Received: 13 January 2016 / Accepted: 13 May 2016 / Published online: 26 May 2016

(c) Springer Science+Business Media Singapore 2016

\begin{abstract}
Glass cover is very important component for the efficient design of the solar still. Sunrays are first incident on glass cover and then transfer to the solar still for the purpose of evaporation of water to get potable water. Selection of the proper glass cover is always based on transmittance and it is depends on thickness of the glass cover. Hence, to study effect of transmittance on glass cover thickness, three different thicknesses of glass cover like $4 \mathrm{~mm}, 5 \mathrm{~mm}$ and $6 \mathrm{~mm}$ were chosen for the study on three same sized solar stills and tested in composite climate conditions of Mehsana, a city of North Gujarat, India during sunshine hours of January 2011 to June 2011. Theoretical and experimental analysis of three different thicknesses of glass cover is carried out by heat and mass transfer analysis to determine the optimum thickness of glass cover for the effective distillate output from solar still and validation between them. After six months of experiments, it has found that $4 \mathrm{~mm}$ and $5 \mathrm{~mm}$ glass cover thickness increased average distillate output of $27 \%$ and $12 \%$ compared with $6 \mathrm{~mm}$ glass cover thickness. Also theoretical results found good match with experimental results.
\end{abstract}

Keywords Solar still · Glass cover · Distillate output . Solar energy

Hitesh Panchal

engineerhitesh2000@gmail.com

1 Department of Mechanical Engineering, Gujarat Power Engineering \& Research Institute, Meshana, Gujarat, India

\section{Introduction}

Depending on the energy available for evaporating the water in the still, the stills are classified into passive and active. In passive stills, the water in the still basin receives heat only by the radiation transmitted through the transparent cover. Hence the performances of this type of stills are improved by optimizing the cover and basin conditions. The cover plate is optimized to receive and transmit maximum radiation into the still. Also, the cover should be capable of condensing maximum mass of water vapour by exhausting heat to the atmosphere. The basin has to receive the maximum radiation transmitted into the still, convert into heat, transfer heat to the water and provide maximum surface area for evaporation. It should also retain excess heat and utilize it when the radiation level falls [8].

The transparent cover receives and transmits radiation into the still. Also, the condensation takes place at its lower surface. Also, it should suppress thermal radiation to the atmosphere. Glass is the best material for cover [7] since it has higher transmittance and less reflectivity. Also glass is opaque for thermal radiation. For higher latitude places, single slope still is preferable and for northern chemosphere the still faces south $[1,5,17,19]$. The inclination of the cover is optimized to collect the accumulated condensate through drain before it drops down to basin. The condensate mass accumulation depends on solar intensity and condensation rate [19] conducted indoor simulation experiment and found that the production rate is higher for $30^{\circ}$ cover inclination. The glass has to withstand its self-weight and thermal stresses. For higher surface area, high thickness glass will be used. But, radiation 
transmittance and heat transfer through the glass decrease with thickness. The transmittance loss at cover is less due to film wise condensation at the lower surface. The other transparent materials are not having these characteristics [8]. The glass cover temperature is reduced by continuous flow [2] or intermittent flow [18] of raw cooling water on the cover. The cooling water gains latent heat from condensing water and regenerates it in the basin. Second effect of evaporation and condensation takes place between the covers. [3] result shows increase in production by $20 \%$. Evacuated tubes played important role for effective utilization of hot water for the increment in distillate output [9-13]. Yousef and Mousa [20] results also show that, the use of the film-cooling increases the still efficiency up to $20 \%$. Wind velocity is also having its effect on temperature of the glass. At higher wind velocity, due to higher convection heat transfer from the glass to atmosphere the productivity of the still is increasing $[4,15,16,20]$. Theoretically analyzed the effect of water flowing over the glass cover in a single basin still. The result shows the productivity is increased with flowing water over the glass cover. Also, the yield decrease when the water flow rate increases. CFX has also played crucial role for designing the solar still. $[10,14]$.

Many researchers have worked on solar still to improve its distillate output and efficiency. But the analysis of glass cover based on transmittance it still unattended by the researchers. Hence, in this present research work, three different sized glass covers transmittance determined by correlation. Theoretical and experimental results of varying glass cover thicknesses were compared and validated by energy balance equations. At last, six months results of different thicknesses glass cover on three same area solar stills compared to find optimum thickness, which is best suited to get enhanced distillate output.

\section{Experimental set up}

Figure 1 shows the experimental setup installed at Gujarat Power Engineering \& Research Institute, Mehsana, India. The bottom part of each still was painted black to increase the solar energy radiation. In this present experiment all stills used with $1 \mathrm{~cm}$ water depth and which is maintained constant by use of solenoid valve attached with each still. Vertical side of the still was at a depth of $0.200 \mathrm{~m}$, whereas the height of the vertical side was kept $0.400 \mathrm{~m}$. The effective basin area of each still is kept as conventional solar still and it is 1 square meter and glass cover angle is kept $23^{\circ}$. It is made of Fiber reinforced plastic (FRP) of $0.050 \mathrm{~m}$ insulation thickness. Here, total seven thermocouples are located inside stills. Among, seven thermocouples, six measured water and glass cover temperatures and seventh exposed to atmosphere to measure ambient temperature. The output from the still is collected through a channel fixed at the end of the smaller vertical side of the basin. A storage tank of total capacity of brackish water is $50 \mathrm{~kg}$ is put at the top at the front wall of Institute to supply raw water into the solar still. Water level inside the still is maintained constant by use of control valve attachment with each solar still. All temperatures, distillate output from all solar stills were stored by data logger. Table 1 shows errors and accuracies of used measuring instruments and Table 2 shows dimensions of each solar still for the research work.

\section{Theoretical Analysis}

\section{Glass cover transmittance}

Glass cover is the top component of solar still. It actually has three major objectives: to reduce radiant and convective
Fig. 1 Experimental set up of solar stills with varying glass cover thicknesses

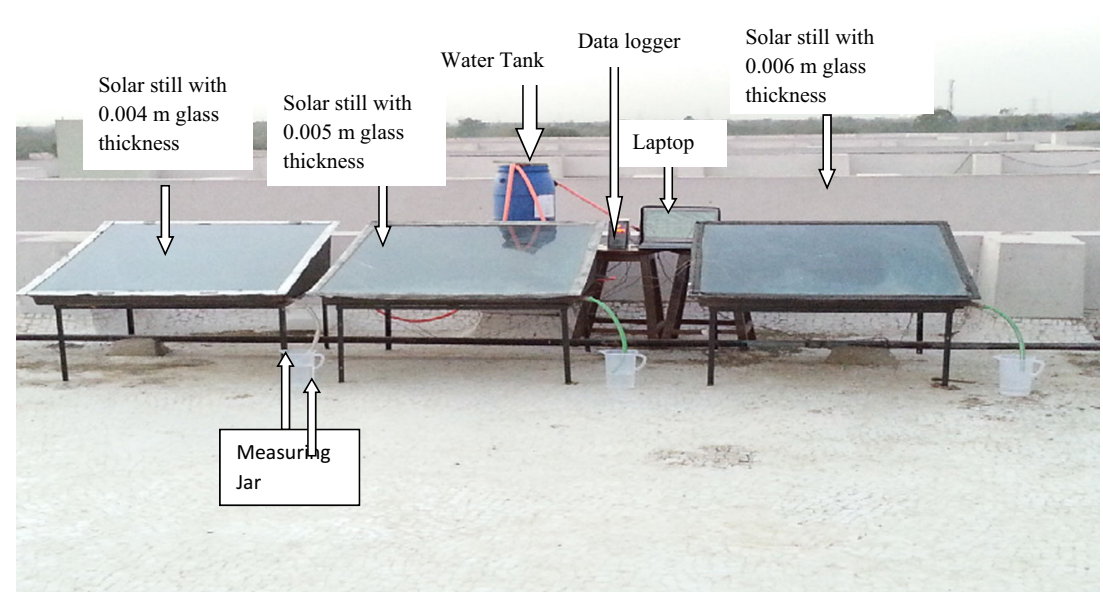


Table 1 Various important instruments with error and range

\begin{tabular}{|c|c|c|c|c|}
\hline Sr. No. & Instrument & Accuracy & Range & $\%$ error \\
\hline 1 & K Type thermocouples & $\pm 0.1{ }^{\circ} \mathrm{C}$ & $0-100^{\circ} \mathrm{C}$ & $5 \%$ \\
\hline 2 & Solarimeter & $\pm 1 \mathrm{~W} / \mathrm{m}^{2}$ & $0-1400 \mathrm{~W} / \mathrm{m}^{2}$ & $2.5 \%$ \\
\hline 3 & Measuring Jar & $\pm 10 \mathrm{ml}$ & $0-1000 \mathrm{ml}$ & $10 \%$ \\
\hline 4 & Anemometer & $\pm 1 \mathrm{~m} / \mathrm{s}$ & $0-15 \mathrm{~m} / \mathrm{s}$ & $10 \%$ \\
\hline
\end{tabular}

heat loss from the absorber plate, to transmit the incoming sun rays to the absorber plate with minimum heat loss, and to protect the absorber plate from surrounding irregularities. Other important features of glass cover materials are absorption, reflection and transmission. To get maximum efficiency with minimum loss of solar radiations, transmission of sunrays should as high as possible and reflection and absorption should be as low as possible, whilst transmission should be as high as possible [18]. Hence, reasons for attention in choosing the glass cover materials comprises of strength of material, toughness, less degradability when open to the ultraviolet light (UV), and low costs. Usually the common materials used as glass cover materials are glass and plastics

Glass cover is the major material used to glaze solar still. Glass cover material has extremely required property of transmitting $90 \%$ or more than $90 \%$ of the sun incoming short-wavelength radiation, while almost none of the long wavelength incoming sun rays discharged by the absorber plate can escape outwards by transmission. Compared to glass cover, a plastic cover possesses high shortand long-wave Transmissivity and hence high performance. Generally, the main advantages of plastics are resistance to breakage, light weight, and low cost. However, plastics have been reported to have limited life span due to the effect of UV radiation which reduces its transmissivity [20]. Also, plastics are transparent to long-wavelength radiation and are therefore less effective in reducing radiated heat losses from the absorber plate. In addition, plastics cannot withstand high temperature encountered in collector especially when the collector is idle.

Table 2 Dimension of solar still

\begin{tabular}{ll}
\hline Parameter & Value \\
\hline Solar still area including basin & $1 \mathrm{~m}^{2}$ \\
Glass cover tilting angle & $23^{\circ}$ \\
Insulation thickness & $0.05 \mathrm{~m}$ \\
\hline
\end{tabular}

Generally glass cover is facing south direction to receive solar radiation at different angle and different quantities in enhanced quantity. Hence incoming solar radiations are:

$\mathrm{Q}_{\mathrm{i}}=\mathrm{Q}_{\mathrm{s}}$

Where, $\mathrm{Q}_{\mathrm{s}} \quad=\mathrm{A}_{\mathrm{g}} \mathrm{I}_{\mathrm{s}}$

The utilization of radiation absorbed by the solar still for any given instant is the total solar radiation transmitted through the south-facing glass cover and is given by:

$\mathrm{Q} \tau=\mathrm{Q} \tau_{\mathrm{s}}$

Where $\mathrm{Q} \tau_{\mathrm{s}}=\tau_{\mathrm{s}} \mathrm{A}_{\mathrm{g}} \mathrm{I}_{\mathrm{s}}$

Transmittance of the glass cover is measured by UV-3600 UV-VIS-NIR Spectrophotometer, available at institute. It is found $0.90,0.84$ and 0.79 for $4 \mathrm{~mm}, 5 \mathrm{~mm}$ and $6 \mathrm{~mm}$ glass cover thickness. But does not remains constant because it is depends on the incoming solar radiation wavelength i.e. short and long wavelength. Hence, the transmittance of the any glass cover is always depends on three parameters namely solar insolation angle of incidence $(\theta)$, coefficient of diffused radiation $\left(\mathrm{K}_{\mathrm{d}}\right)$ and thickness of glass cover $(\mathrm{d})$. Hence, from above three parameters, [6] have developed a important correlation equation for to determine transmittance of a glass cover and it is used for the study (Fig. 2).

\section{Energy balance equations}

In order to write energy balance equations for solar still, following assumptions have been made:

- Condensation of the glass cover is film type.

- There is one dimensional heat flow through back insulation.

- Every hour steady state condition is reached 


\section{Inner glass cover energy balance}

$\alpha_{g}^{\prime} I(t)+\left[q_{r g}+q_{c w}+q_{e w}\right]=q_{c g}$

or

$\alpha_{g}^{\prime} I(t)+h_{1}\left(T_{w}-T_{c i}\right)=\frac{K_{g}}{L_{g}}\left(T_{c i}-T_{c o}\right)$

\section{Outer glass cover energy balance}

$$
\begin{gathered}
\frac{K_{g}}{L_{g}}\left(T_{c i}-T_{c o}\right)=q_{r g}+q_{c g} \\
\frac{K_{g}}{L_{g}}\left(T_{c i}-T_{c o}\right)=h_{2}\left(T_{c i}-T_{a}\right)
\end{gathered}
$$

Hence, put value of Eq. 6 in Eq. 4

$$
\alpha_{g}^{\prime} I(t)+h_{1}\left(T_{w}-T_{c i}\right)=h_{2}\left(T_{c i}-T_{a}\right)
$$

\section{Energy balance for water inside solar still}

$\alpha_{w}^{\prime} I(t)+q_{b}=(M C)_{w} \frac{d T_{w}}{d t}+\left[q_{r w}+q_{c w}+q_{e w}\right]$

or

$\alpha_{w}^{\prime} I(t)+h_{3}\left(T_{b}-T_{w}\right)=(M C)_{w} \frac{d T_{w}}{d t}+h_{1}\left(T_{w}-T_{c i}\right)$

\section{Energy balance for basin liner}

$\alpha_{b}^{\prime} I(t)=q_{w}+\left[q_{b b}+q_{b s}\right]$ or

$\alpha_{b}^{\prime} I(t)=h_{3}\left(T_{b}-T_{w}\right)+U_{b}\left(T_{b}-T_{a}\right)$

For determining expression for Tci, Eq. 7 can be rearranged as:

$$
\begin{array}{r}
\alpha_{g}^{\prime} I(t)=h_{1}\left(T_{w}-T_{c i}\right)=h_{2}\left(T_{c i}-T_{a}\right) \\
\alpha_{g}^{\prime} I(t)+h_{1} T_{w}-h_{1} T_{g}=h_{2} T_{g}-h_{2} T_{a} \\
\alpha_{g}^{\prime} I(t)+h_{1} T_{w}+h_{2} T_{a}=\left(h_{1} T_{c i}+h_{2} T_{c i}\right) \\
\alpha_{g}^{\prime} I(t)+h_{1} T_{w}+h_{2} T_{a}=\left(h_{1}+h_{2}\right) T_{c i} \\
T_{c i}=\frac{\alpha_{g}^{\prime} I(t)+h_{1} T_{w}+h_{2} T_{a}}{h_{1}+h_{2}}
\end{array}
$$

For determining expression for Tb, Eq. 11 can be written as:

$$
\begin{array}{r}
\alpha_{b}^{\prime} I(t)=h_{3}\left(T_{b}-T_{w}\right)+U_{b}\left(T_{b}-T_{a}\right) \\
\alpha_{b}^{\prime} I(t)=h_{3} T_{b}-h_{3} T_{w}+U_{b} T_{b}-U_{b} T_{a} \\
\alpha_{b}^{\prime} I(t)+h_{3} T_{w}+U_{b} T_{a}=h_{3} T_{b}+U_{b} T_{b} \\
T_{b}=\frac{\alpha_{b}^{\prime} I(t)+h_{3} T_{w}+U_{b} T_{a}}{h_{3}+U_{b}}
\end{array}
$$

Now put values of $\mathrm{T}_{\mathrm{ci}}$ and $\mathrm{T}_{\mathrm{b}}$ in Eq. 9

$\alpha_{w}^{\prime} I(t)+h_{3}\left(T_{b}-T_{w}\right)=(M C)_{w} \frac{d T_{w}}{d t}+h_{1}\left(T_{w}-T_{c i}\right)$

Now Divide whole Eq. 14 by (MC)w, then it becomes

$$
\begin{gathered}
\frac{\alpha_{w}^{\prime} I(t)+h_{3}\left(T_{b}-T_{w}\right)}{(M C)_{w}}=\frac{d T_{w}}{d t}+\frac{h_{1}\left(T_{w}-T_{c i}\right)}{(M C)_{w}} \\
\frac{\alpha_{w}^{\prime} I(t)+\left(h_{3}\left[\frac{\alpha_{b}^{\prime} I(t)+h_{3} T_{w}+U_{b} T_{a}}{\left(h_{3}+U_{b}\right)}\right]-T_{w}\right)}{(M C)_{w}}=\frac{d T_{w}}{d t}+\frac{\frac{h_{1}\left(T_{w}-\left[\alpha_{g}^{\prime} I(t)+h_{1} T_{w}+h_{2} T_{a}\right]\right)}{\left(h_{1}+h_{2}\right)}}{(M C)_{w}}
\end{gathered}
$$

rearranging above (15) as,

$$
\begin{gathered}
\frac{\frac{\alpha_{b}^{\prime} h_{w}}{h_{w}+h_{3}}+\alpha_{w}^{\prime}+\alpha_{g}^{\prime} \frac{h_{1}}{h_{1}+h_{2}} \times I(t)+\left(\frac{h_{w} h_{3}}{h_{w}+h_{3}}+\frac{h_{1} h_{2}}{h_{1}+h_{2}}\right) \times T_{a}}{(M C)_{w}}=\frac{d T_{w}}{d t}+\frac{\left(\frac{h_{w} h_{3}}{h_{w}+h_{3}}+\frac{h_{1} h_{2}}{h_{1}+h_{2}}\right)}{(M C)_{w}} \\
\frac{(\alpha \tau)_{e f f} I(t)+U_{L} T_{a}}{(M C)_{w}}=\frac{d T_{w}}{d t}+\frac{U_{L}}{(M C)_{w}} T_{w}
\end{gathered}
$$


Equation 16 can be rearranging as,

$$
\begin{array}{r}
f(t)=\frac{d T_{w}}{d t}+a T_{w} \\
\text { where, } f(t)=\frac{(\alpha \tau)_{e f f} I(t)+U_{L} T_{a}}{(M C)_{w}} \\
\text { where, }(\alpha \tau)_{\text {eff }}=\alpha_{b} \frac{h_{w}}{h_{w}+h_{3}}+\alpha_{w}^{\prime}+\alpha_{g}^{\prime} \frac{h_{1}}{h_{1}+h_{2}} \\
a=\frac{U_{L}}{(M C)_{w}} \\
\text { where, } U_{L}=U_{b}+U_{t} \\
\text { where, } U_{b}=\frac{h_{w} h_{3}}{h_{w}+h_{3}}, U_{t}=\frac{h_{1} h_{2}}{h_{1}+h_{2}}
\end{array}
$$

The rate of evaporative heat loss and the hourly yield of the solar still are given as:

$q_{e w}=h_{e w}\left(T_{w}-T_{c i}\right)$

And

$m=\frac{h_{e w}\left(T_{w}-T_{c i}\right)}{L} \times 3600$

The daily distillate output is given by

$M_{e w}=\sum_{i=1}^{24} M_{e w}$

Efficiency is determined by:

$\eta=\frac{h_{e w}\left(T_{w}-T_{c i}\right)}{I * A}$

\section{Result and Discussion}

The following design parameters used in Table 2 to determine the theoretical results based on the equations used in the energy balance equations:

\begin{tabular}{ll}
\hline$\alpha_{\mathrm{b}}$ & 0.36 \\
$\alpha_{\mathrm{g}}$ & 0.05 \\
$\alpha_{\mathrm{w}}$ & 0.34 \\
$\mathrm{~F}_{\mathrm{R}}$ & 0.831 \\
$\mathrm{M}_{\mathrm{w}}$ & $30 \mathrm{~kg}$ \\
$\varepsilon_{\text {eff }}$ & 0.82 \\
$\mathrm{~L}_{\mathrm{i}}$ & $0.05 \mathrm{~m}$ \\
$\mathrm{~K}_{\mathrm{i}}$ & $0.57 \mathrm{~W} / \mathrm{m} \mathrm{K}$ \\
$\mathrm{h}_{\mathrm{W}}$ & $250 \mathrm{~W} / \mathrm{m}^{2} \mathrm{~K}$ \\
$\mathrm{t}$ & $3600 \mathrm{~s}$ \\
$\mathrm{C}_{\mathrm{w}}$ & $4190 \mathrm{~J} / \mathrm{Kg} \mathrm{K}$ \\
$\sigma$ & $5.67 \times 10^{-8} \mathrm{~W} / \mathrm{m}^{2} \mathrm{~K}$ \\
$(\alpha \tau)_{\mathrm{c}}$ & 0.8 \\
$\mathrm{U}_{\mathrm{LC}}$ & $2.44 \mathrm{~W} / \mathrm{m}^{2} \mathrm{~K}$ \\
$\mathrm{~h}_{2}$ & $5.7+3.8 \mathrm{~V}, \mathrm{~V}=3 \mathrm{~m} / \mathrm{s}$ \\
$\mathrm{L}$ & $2.25 \times 10^{5} \mathrm{~J} / \mathrm{Kg}$ \\
\hline
\end{tabular}

The alternating climate factors such as solar insolation and ambient temperature have been calculated by standard calibrated instruments and variable parameters used in theoretical calculations.

Experiments have been carried out with varying glass cover thicknesses on different days continuously during January to June 2011 during sunshine days. The solar insolation condition remains equal for all days of the months and observations have been compared for such days only. Among such days having variation in the ambient conditions are same and the days having variation in the ambient conditions are ignored. Figure 3 shows the variation of solar insolation and ambient temperature for the days in which observations made with three different solar stills having different glass cover thicknesses. Solar insolation falling on each solar still would be same. Hence, the single curve is shown and it shows that, solar insolation seems to be maximum between the 12 to $1 \mathrm{pm}$ for all solar stills.

Figure 4 exhibits the variation of total solar insolation fraction including diffused radiation fraction and transmittance of the south facing glass covers having different thicknesses. Correlation proposed by for the transmittance has been used in the present work and it was same for all incident angles of solar radiation on all solar stills. Eventhough the angle of incidence of solar rays is higher during morning as well as evening hours and reverse during noon, hence transmittance will be higher during morning and noon and lower during the noon hours.

Figure 5 exhibits the variations of distillate output production for varying glass cover thicknesses in solar stills throughout the day for 24 hours. Here, $1 \mathrm{~cm}$ water depth in each solar still is made constant by use of solenoid valve attachment for the proper comparison of distillate output in each still. From the graph, it is clearly shown that, 4 mm glass cover thickness solar still have obtained higher distillate output throughout the day, when compared with other solar stills having $5 \mathrm{~mm}$ and $6 \mathrm{~mm}$ glass cover thicknesses. The reason behind getting higher distillate output, is higher transmittance of glass cover for $4 \mathrm{~mm}$ glass cover thickness, which allows enhanced solar radiation falling on water inside solar still. Figure 6 shows the total distillate output obtained by each solar still for 24 hours of time interval. It is clear that, total distillate output of $4 \mathrm{~mm}, 5 \mathrm{~mm}$ and $6 \mathrm{~mm}$ thickness solar still found $2.51 \mathrm{~kg}, 2.0 \mathrm{~kg}$ and $1.49 \mathrm{~kg}$. Among all solar stills, $4 \mathrm{~mm}$ glass cover thickness found $0.342 \mathrm{~kg}$ distillate output during off-sunshine hours and remaining $5 \mathrm{~mm}$ and $6 \mathrm{~mm}$ glass cover thickness found 0.259 and $0.195 \mathrm{~kg}$. Hence, it is proved that, $4 \mathrm{~mm}$ glass cover thickness solar still is efficient for producing distillate output not only during sunshine hours but also off-sunshine hours.

Distillate water is a key factor for the efficient design of solar still. But for getting distillate output, water and inner 
Fig. 2 Overall Energy-balance equations of sola still

Fig. 3 Hourly variations of solar insolation solar stills for varying glass cover thicknesses
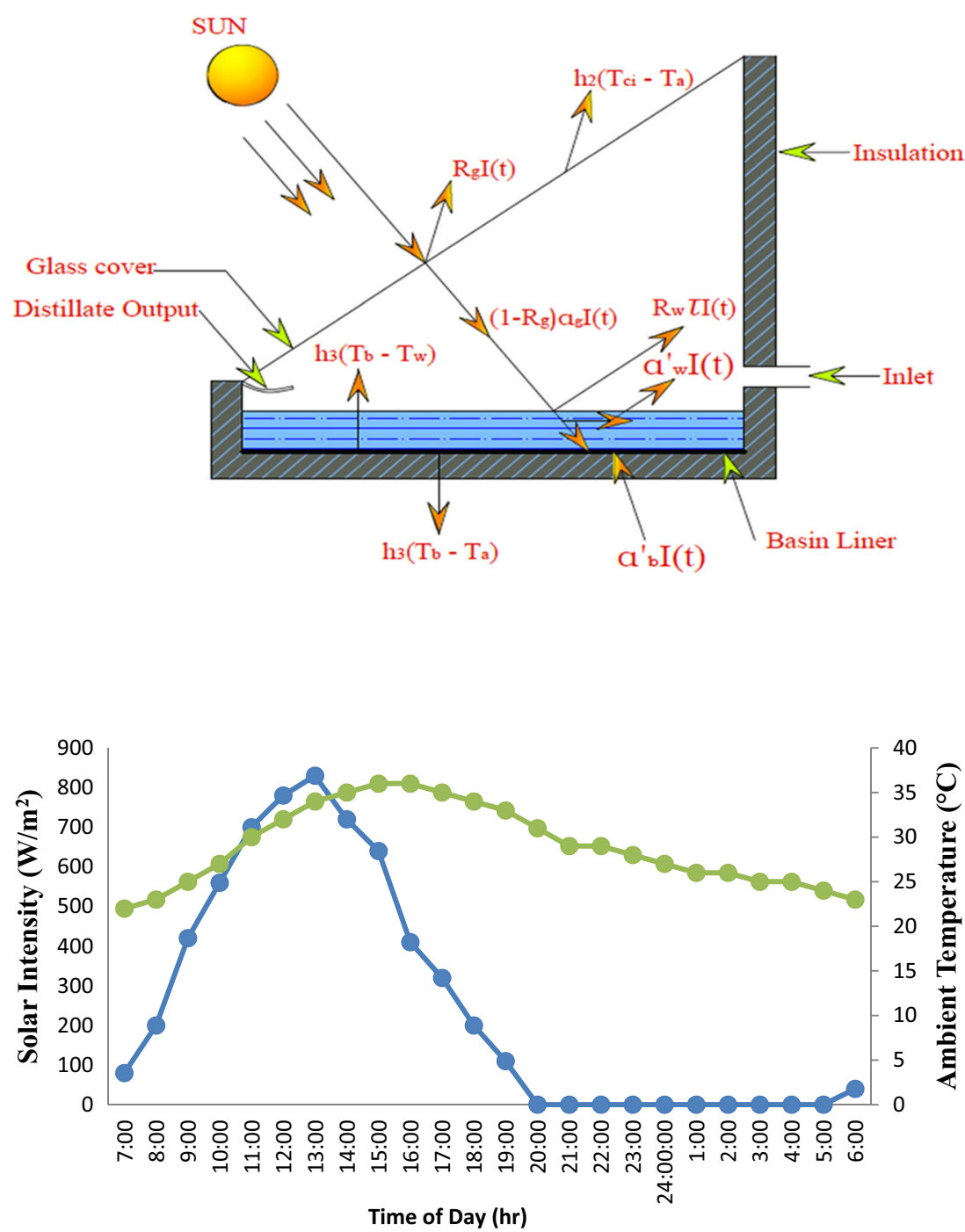

Fig. 4 Hourly Variations of Solar insolation including diffuse radiation fraction and transmittance for solar stills varying glass cover thicknesses

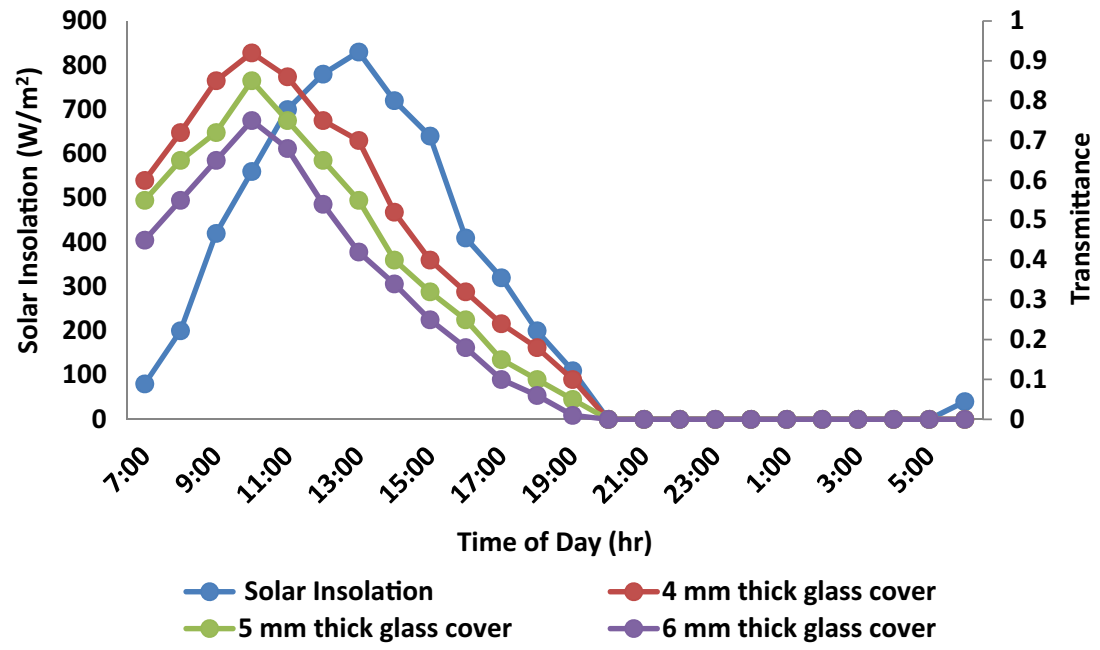


Fig. 5 Variations of hourly distillate output for solar stills having varying glass cover thicknesses

Fig. 6 Variations of total distillate output obtained from solar stills having varying glass cover thicknesses

Fig. 7 Hourly variations of water and inner glass cover temperatures

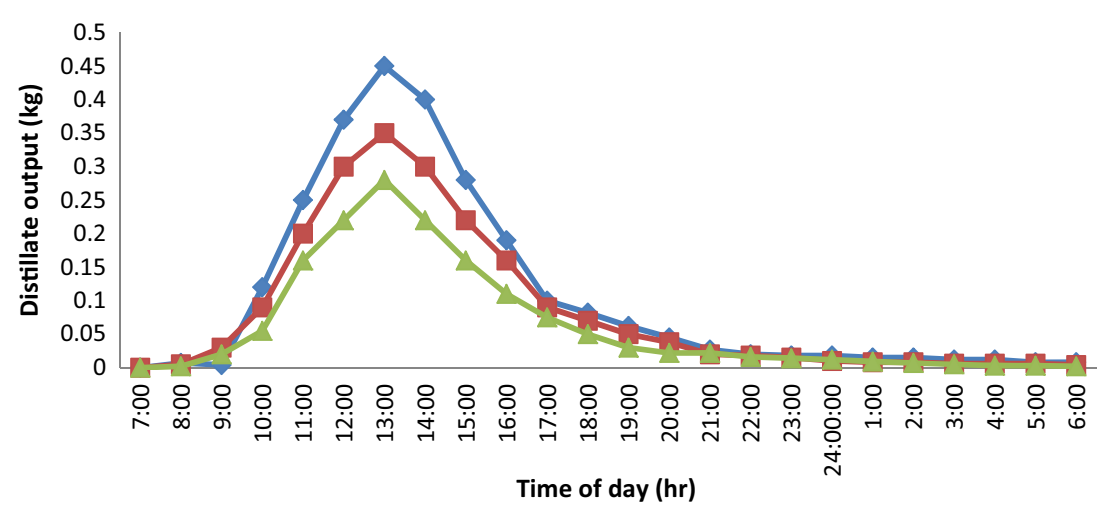

$\multimap 4$ mm glass thickness $\quad-5 \mathrm{~mm}$ glass thickness $\quad-6 \mathrm{~mm}$ glass thickness
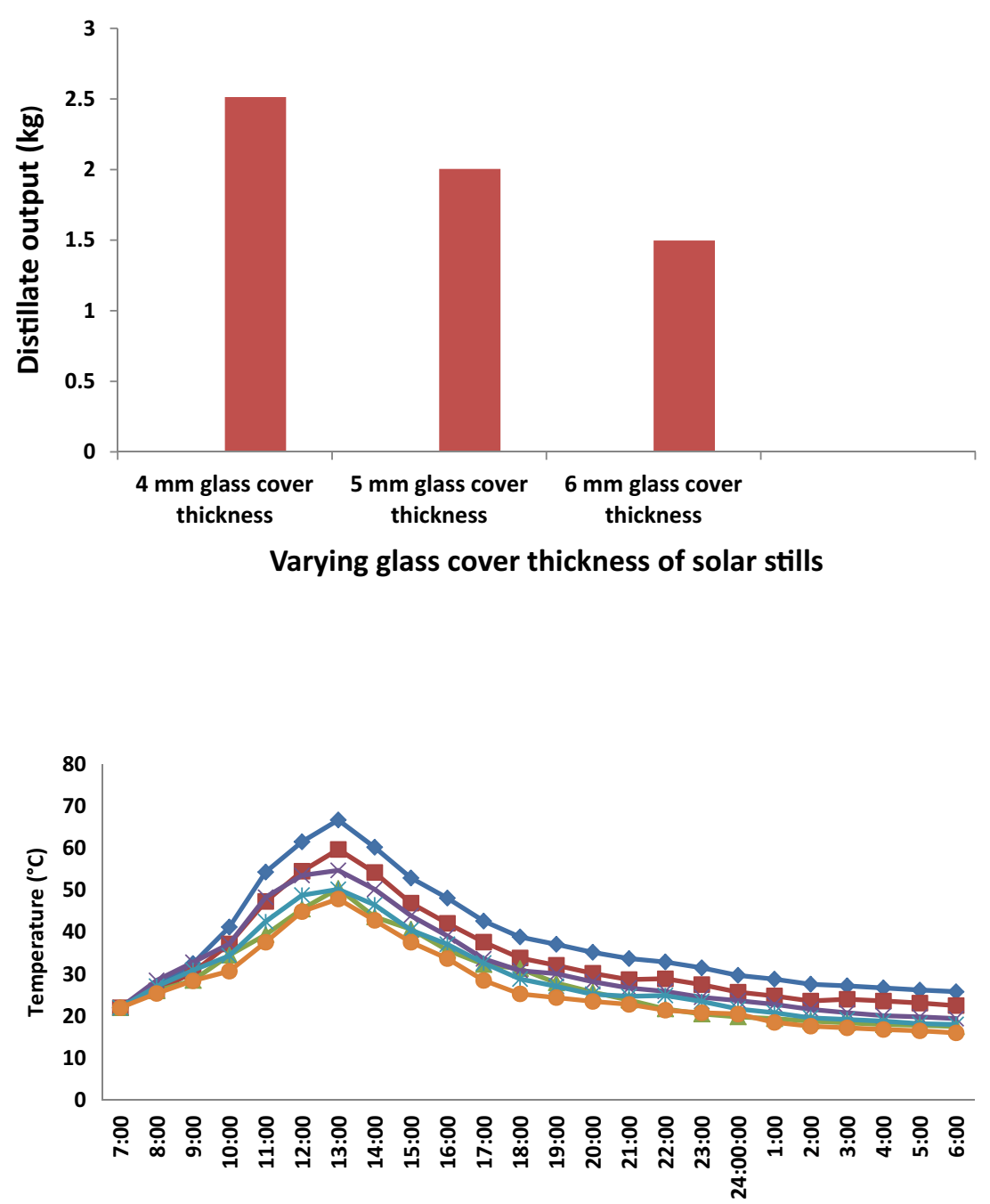

Time of day (hr)

$\multimap$ Tw $4 \mathrm{~mm}$ thick glass cover $\quad-$ Tw $5 \mathrm{~mm}$ thick glass cover $\rightarrow$ Tw $6 \mathrm{~mm}$ thick glass cover *Tci $4 \mathrm{~mm}$ thick glass cover $\quad$-Tci $5 \mathrm{~mm}$ thick glass cover $-\rightarrow$ Tci $5 \mathrm{~mm}$ thick glass cover 
Fig. 8 Hourly variations of theoretical and actual water temperature for solar still having $4 \mathrm{~mm}$ glass cover thickness

Fig. 9 Hourly variations of theoretical and actual inner glass cover water temperature for solar still having $4 \mathrm{~mm}$ glass cover thickness

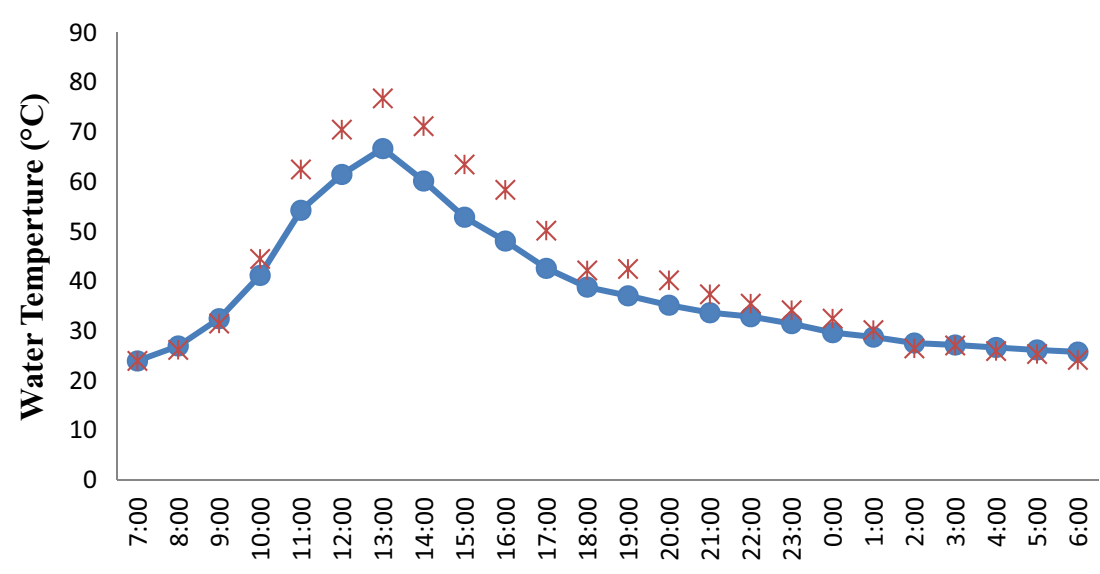

Time (h)

$\longrightarrow$ Tw (Actual)

* Tw (Theoretical)

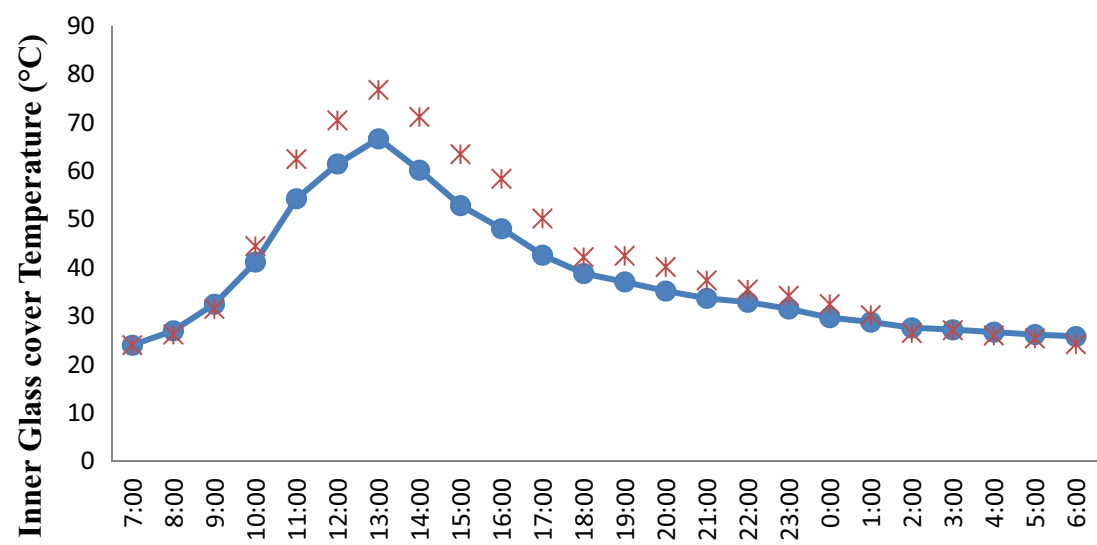

Time (h)

-Tci (Experimental) $\quad$ * Tci (Theoretical)

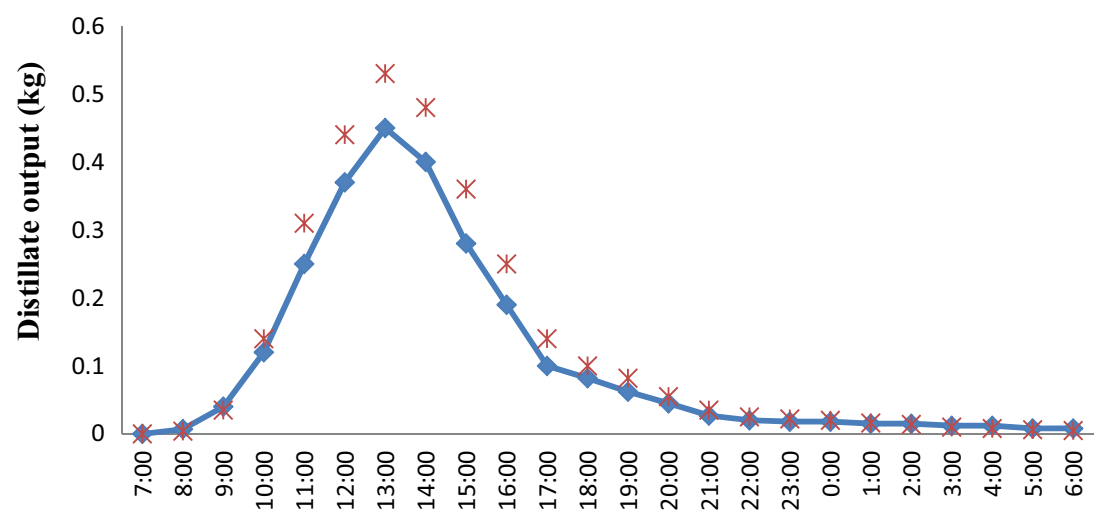

Time (h)

$* \mathrm{~m}$ (Theoretical)

Fig. 10 Hourly variations of theoretical and actual distillate output for solar still having 4 mm glass cover thickness 
Fig. 11 Hourly variations of efficiency for varying glass cover thicknesses in solar stills

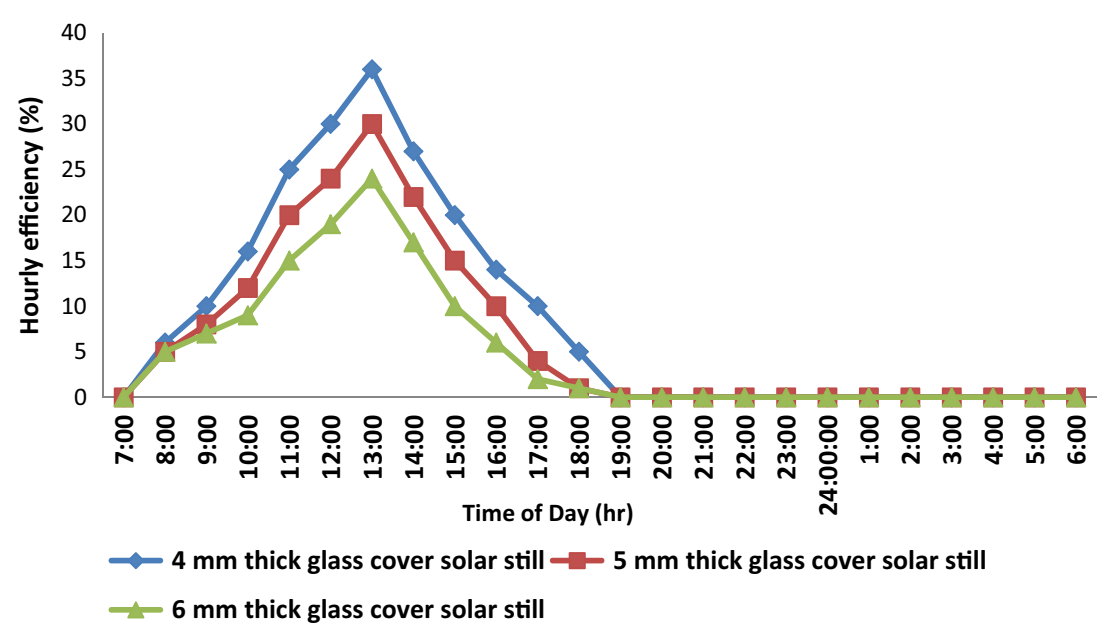

glass cover temperatures are as important as distillate output. Hence, hourly variations of water and inner glass cover temperatures have been measured for each solar stills and shown in Fig. 7. It is clear that, trend of graph for all solar still having varying glass cover. It is also found that, water and inner glass cover temperature found maximum during 1 pm for each still.

A computer program has been written as Microsoft Excel -2010 for the analytical solutions for the various parameters like water temperature, inner glass cover temperature and distillate output for solar still having $4 \mathrm{~mm}$ glass cover thickness is shown in Figs. 8, 9 and 10 respectively. It is clearly shown that, experimental results found good match with theoretical results. At some stages i.e. back and side walls of solar still basin, little deviations found but it is negligible, hence it is not create any disturbance in the comparison.

Efficiency is also one of the most important parameters for performance of any solar still. It shows the percentage of conversion of raw water into potable water hour by hour. Figure 11 exhibits variation of efficiency with respect to time. It is clearly demonstrated that, efficiency is increased from morning 07:00 am to 13:00 pm and then decrease because of availability of solar insolation. It is also found that, $4 \mathrm{~mm}, 5 \mathrm{~mm}$ and $6 \mathrm{~mm}$ glass cover thickness solar stills found 27, 22 and $17 \%$ efficiency during 01:00 pm at noon.

Table 3 shows average daily and monthly distillate output gained by varying the glass cover thickness during the months of January - June 2011. It is clearly demonstrated that, $4 \mathrm{~mm}$ glass cover thickness solar still found higher distillate output during all experimental days during January - June 2011 compared with $5 \mathrm{~mm}$ and $6 \mathrm{~mm}$ thickness solar still. Least and higher distillate output gained during the months of May and January, 2011. The average distillate output of each solar still is calculated by dividing summation of each day distillate output by number of days. Average monthly distillate output is computed by multiplying the average daily distillate output with a number of clear sky days. Hence, the average distillate output gained by $4 \mathrm{~mm}, 5 \mathrm{~mm}$ and $6 \mathrm{~mm}$ glass cover thickness found 337.94, 299.92 and $265.58 \mathrm{~kg}$ distillate output. Hence, percentage increments in distillate output of $4 \mathrm{~mm}$ thickness solar still

Table 3 Daily, Monthly Distillate Output obtained Solar Stills with Varying Glass Cover thicknesses during January - June 2011

\begin{tabular}{|c|c|c|c|c|c|c|c|}
\hline \multirow[t]{2}{*}{ Month of the year } & \multirow[t]{2}{*}{ No. of clear sky days } & \multicolumn{3}{|c|}{ Average daily yield (Kg) } & \multicolumn{3}{|c|}{ Average monthly yield } \\
\hline & & $4 \mathrm{~mm}$ thick & $6 \mathrm{~mm}$ thick & $8 \mathrm{~mm}$ thick & $4 \mathrm{~mm}$ thick & $6 \mathrm{~mm}$ thick & $8 \mathrm{~mm}$ thick \\
\hline January-2011 & 22 & 1.4 & 1.25 & 1.15 & 30.8 & 27.5 & 25.3 \\
\hline February-2011 & 24 & 1.52 & 1.28 & 1.22 & 36.48 & 30.72 & 29.28 \\
\hline March-2011 & 28 & 2.32 & 2.1 & 1.8 & 64.96 & 58.8 & 50.4 \\
\hline April-2011 & 30 & 2.54 & 2.3 & 2.1 & 76.2 & 69 & 63 \\
\hline May - 2011 & 30 & 2.85 & 2.55 & 2.3 & 85.5 & 76.5 & 69 \\
\hline June - 2011 & 22 & 2 & 1.7 & 1.3 & 44 & 37.4 & 28.6 \\
\hline Average & & 12.63 & 11.18 & 9.87 & 337.94 & 299.92 & 265.58 \\
\hline
\end{tabular}


is $12 \%$ compared with $5 \mathrm{~mm}$ and $27 \%$ compared with 6 mm thickness

\section{Conclusion}

From the present research work, following points are concluded:

- Performance analysis of single basin single slope solar results with experimental results.

- Solar still having $4 \mathrm{~mm}$ glass cover thickness is found transmittance of solar rays.

- Solar still having $4 \mathrm{~mm}$ glass cover thickness is not only during sunshine hours.

- Solar still having $4 \mathrm{~mm}$ glass cover thickness found $27 \%$

- After 6 months of continuous experiments on solar stills thickness.

\section{Nomenclatures}

\section{Symbol}

Notation

$\alpha_{g}^{\prime}$

$\alpha_{w}^{\prime}$

$\alpha_{b}^{\prime}$

$(\mathrm{MC})_{\mathrm{W}}$

$\mathrm{A}_{\mathrm{S}}$

$\mathrm{h}_{1}$

$\mathrm{h}_{2}$

$\mathrm{h}_{3} \quad$ Heat transfer coefficient from

basin to atmosphere

$\mathrm{h}_{\mathrm{cw}} \quad$ Convective heat transfer

coefficient

$\mathrm{h}_{\mathrm{ew}} \quad$ Evaporative heat transfer coefficient

Absorptivity of glass cover

Absorptivity of water

Absorptivity of basin

Heat stored by the water

Area of Solar still

Total heat transfer coefficient

Heat transfer coefficient from

glass cover to ambient still has been theoretically modeled by consideration of transmittance and solar insolation of south facing glass cover and validated experimentally for typical days of experiments and found good matching of theoretical among other solar stills having $5 \mathrm{~mm}$ and $6 \mathrm{~mm}$ glass thickness to increase distillate output by increasing increasing distillate output during sunshine hours but also during off-sunshine hours due to getting more heat hourly efficiency compared with $22 \%$ of $5 \mathrm{~mm}$ thickness solar still and $17 \%$ of $6 \mathrm{~mm}$ thickness solar still. having variations in glass cover thickness, it has been found that, solar still having $4 \mathrm{~mm}$ glass cover thickness and $5 \mathrm{~mm}$ glass cover thicknesses found $27 \%$ and $12 \%$ increment compared with solar still having $6 \mathrm{~mm}$

$h_{r w}$

$\mathrm{h}_{\mathrm{rw}}$

$\mathrm{h}_{\mathrm{W}}$

I(t)

$\mathrm{K}_{\mathrm{g}}$

L

$\mathrm{L}_{\mathrm{g}}$

m

$\mathrm{M}_{\mathrm{ew}}$

$\mathrm{M}_{\mathrm{w}}$

N

$\mathrm{q}_{\mathrm{b}}$

$\mathrm{q}_{\mathrm{cg}}$

$\mathrm{q}_{\mathrm{cw}}$

qew

$\mathrm{q}_{\mathrm{rg}}$

$\mathrm{Q}_{\mathrm{i}}$

$\mathrm{Q}_{\mathrm{s}}$

$\mathrm{T}$

$\mathrm{Q}_{\mathrm{Ts}}$

t

Units

$\mathrm{T}_{\mathrm{a}}$

$\mathrm{T}_{\mathrm{a}}$
$\mathrm{T}_{\mathrm{b}}$

$\mathrm{T}_{\mathrm{co}}$

$\mathrm{T}_{\mathrm{g}}$ or $\mathrm{T}_{\mathrm{ci}}$

$\mathrm{kJ} / \mathrm{kg}$

$\mathrm{m}^{2}$

$\mathrm{W} / \mathrm{m}^{2 \circ} \mathrm{C}$

$\mathrm{W} / \mathrm{m}^{2 \circ} \mathrm{C}$

$\mathrm{T}_{\mathrm{w}}$

$\mathrm{W} / \mathrm{m}^{2 \circ} \mathrm{C}$

$\mathrm{U}_{\mathrm{b}}$

$\mathrm{U}_{\mathrm{b}}$

$\mathrm{W} / \mathrm{m}^{2 \circ} \mathrm{C}$

$\mathrm{U}_{\mathrm{L}}$

$\mathrm{W} / \mathrm{m}^{2 \circ} \mathrm{C}$
Radiative heat transfer coefficient

Radiative heat transfer coefficient

Enthalpy of water

Insolation on solar still

Thermal Conductivity of glass cover

Latent heat of vaporization

Thickness of glass cover

Distillate output gained by

passive solar still

Total distillate output gained

by passive solar still at end

of each day

the saline tank

Number of observations

Rate of heat transfer from basin

rate of energy lost from the

glass cover by convective

Rate of energy lost from water by convection

Rate of energy lost from water by evaporation

Rate of energy lost from glass cover by radiation

Total solar radiations on solar still W/ $\mathrm{m}^{2}$

Total solar radiation falling on south facing glass cover

Total solar radiation

transmitted to solar still

Total solar radiation

transmitted through the solar

facing glass cover

Time interval for the

experient (3600 s)

Ambient temperature

Temperature of basin

Outer glass cover temperature

Tempertaure of inner side

glass cover

Temperature of water inside

passive solar still

Heat transfer loss from

basin $\mathrm{W} / \mathrm{m}^{2}$

Total Bottom loss from

passive solar still

Total heat transfer loss from

passive solar still

Total top loss from

passive solar still
$\mathrm{W} / \mathrm{m}^{2 \circ} \mathrm{C}$

$\mathrm{W} / \mathrm{m}^{2 \circ} \mathrm{C}$

$\mathrm{W} / \mathrm{m}^{2}$

$\mathrm{W} / \mathrm{m}^{2}$

$\mathrm{W} / \mathrm{m} \mathrm{K}$

$\mathrm{kJ} / \mathrm{kg}$

$\mathrm{M}$

$\mathrm{kg}$

$\mathrm{kg}$

$\mathrm{kg}$

$\mathrm{W} / \mathrm{m}^{2}$

$\left(\mathrm{W} / \mathrm{m}^{2}\right)$

$\mathrm{W} / \mathrm{m}^{2}$

$\mathrm{W} / \mathrm{m}^{2}$

$\mathrm{W} / \mathrm{m}^{2}$

$\mathrm{W} / \mathrm{m}^{2}$

$\mathrm{W} / \mathrm{m}^{2}$

$\mathrm{W} / \mathrm{m}^{2}$

$\mathrm{W} / \mathrm{m}^{2}$

Second

${ }^{\circ} \mathrm{C}$

${ }^{\circ} \mathrm{C}$

${ }^{\circ} \mathrm{C}$

${ }^{\circ} \mathrm{C}$

${ }^{\circ} \mathrm{C}$

$\mathrm{W} / \mathrm{m}^{2}$

$\mathrm{W} / \mathrm{m}^{2}$

$\mathrm{W} / \mathrm{m}^{2}$

$\mathrm{W} / \mathrm{m}^{2}$ 


\section{References}

1. ArifIleri ARG (1997) Software to analyze solar stills and an experimental study on the effects of the cover. Desalination 114:37-44

2. A/K Abu-Hijleh B (1996) Enhanced solar still performance using water film cooling of the glass cover. Desalination 107:235244

3. A/K Abu-Hijlew B, Mousa HA (1997) Water film cooling over the glass cover of a solar still including evaporation effects. Energy 22(1):43-48

4. El-Sebaii AA (2000) Effect of wind speed on some designs of solar stills. Energy Convers Manag 41:523-538

5. Fath HES, El-Samanoudy M, Fahmy K, Hassabou A (2003) Thermal-economic analysis and comparison between pyramidshaped and single slope solar still configurations. Desalination 159:69-79

6. Murugavel KK, Chockalingam KNKSK, Srithar K (2008) An experimental study on single basin double slope simulation solar still with thin layer of water in the basin. Desalination 220:687693

7. Karlsson J, Roos A (2000) Modelling the angular behavior of the total solar energy transmittance of windows. Solar Energy 69:321329

8. Malik MAS, Tiwari GN, Kumar A, Sodha MS (1982) Solar Distillation

9. Hitesh P, Shah P (2013) Modeling and verification of hemispherical solar still using ANSYS CFD. Int J Energy Environ 4(3):427-440

10. Panchal H (2013) Enhancement of distillate output of double basin solar still with vacuum tubes. Journal of King Saud UniversityEngineering Sciences 8:101-109
11. Panchal H, Pravin S (2013) Performance analysis of double basin solar still with evacuated tubes. Appl Solar Energy 49(3):174-179

12. Panchal H, Pravin S (2014) Investigation on performance analysis of a novel design of the vacuum tube-assisted double basin solar still: an experimental approach, International Journal of Ambient Energy, doi:10.1080/01430750.2014.924435

13. Panchal H, Pravin S (2015) Enhancement of upper basin distillate output by attachment of vacuum tubes with double-basin solar still. Int J Desalination Water Treat 55(3):587-595

14. Panchal H, Doshi M, Keyursinh T, Anup P (2011) Experimental investigation on coupling evacuated glass tube collector on single slope single basin solar still productivity. Int J Mech Eng Technol $1: 1-9$

15. Panchal H, Pravin S (2011) Modelling and verification of single slope solar still using ANSYS-CFX. Int J Energy Environ 2(6):985-998

16. Panchal H, Pravin S (2012) Effect of Varying Glass cover thickness on Performance of Solar still: in a Winter Climate Conditions. Int J Renew Energy Res 1(4):212-223

17. Singw AK, Tiwari GN, Sharma PB, Khan E (1995) Optimization of orientation for higher yield of solar still for a given location. Energy Convers Manag 36:175-187

18. Tiwari GN, Garg HP (1985) Effect of water flow over the glass cover of a single basin solar still with an intermittent flow of waste hot water in the basin. Energy Convers Manag 25:315-322

19. Tiwari GN, Thomas JM, Khan E (1994) Optimisation of glass cover inclination for maximum yield in a solar still. Heat Recover Syst CHP 14:447-455

20. Yousef H, Abu-Arabi M (2004) Modelling and performance analysis of a regenerative solar desalination unit. Appl Therm Eng 24:1061-1072 